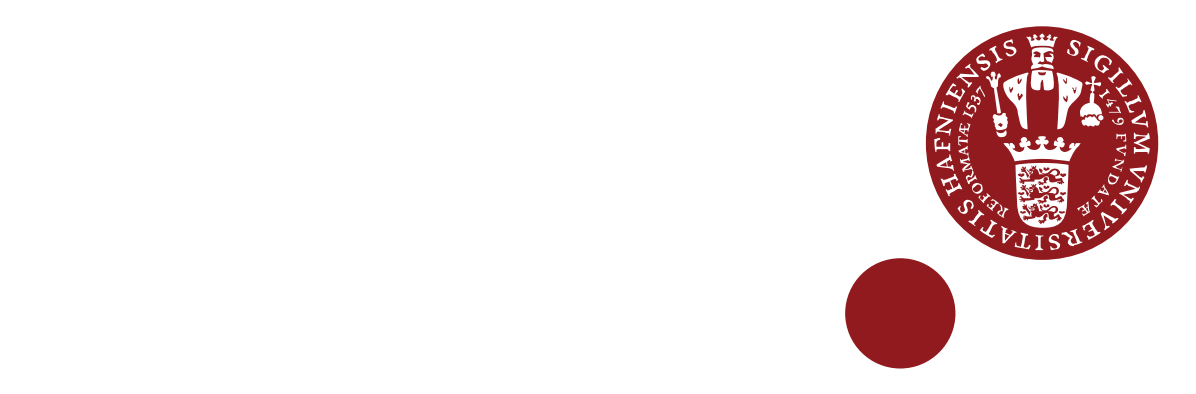

\title{
iCourts
}

iCourts Working Paper Series, no. 219, 2020

\section{That's an Order! \\ The Orders of the CJEU and the Effect of Article 99 RoP on Judicial Cooperation}

Urška Šadl, Daniel Naurin, Lucia López Zurita, Stein Arne Brekke

iCourts - The Danish National Research Foundation's Centre of Excellence for International Courts 


\begin{abstract}
:
The benefits of timely justice and rigorous judicial argument are impossible to overstate and hard to reconcile. In its struggle to deliver both, the Court of Justice of the European Union has initiated several reforms of its procedures. The so-called adjudicating orders arguably achieve the impossible: They fast-track recurring questions while safeguarding legal coherence. The present article unpacks this premise. It shows that seemingly inconsequential procedural amendments, often overlooked by scholars, give the Court full control over relevant European legal problems, and centralize its power.

Concretely, the analysis introduces a typology of orders of the Court, to demonstrate the unique legal character of adjudicating orders. It then investigates their effects against the backdrop of manifold procedural reforms and institutional adjustments. The findings indicate that the greatest efficiency gains follow reforms, which the Court initiates and implements in relative anonymity. Moreover, the use of adjudicating orders increases in response to a sudden and considerable increase of legally similar preliminary references from one Member State. An equal increase of references from the courts of several Member States has no such effect.

The findings suggest that the Court uses adjudicating orders to disengage from 'local' problems and unilaterally terminate the conversations with resolute national courts. Thereby, the preliminary reference procedure, envisaged and promoted as a collaborative tool, transforms into a centralized mechanism of speedy and authoritative dispute resolution.
\end{abstract}

KEYWORDS: the CJEU, adjudication, dispute resolution, European Union Law, judicial cooperation

Urška Šadl, Professor of Law at European University Institute, Florence, Italy, and Global Research Fellow at iCourts, University of Copenhagen, Copenhagen, Denmark urska.sadl@jur.ku.dk

Daniel Naurin, Professor of political science at the University of Oslo and Gothenburg and Director of ARENA daniel.naurin@pol.gu.se

Lucia López Zurita, PhD candidate at the European University Institute (EUI) in Florence lucia.lopez@eui.eu

Stein Arne Brekke, $\mathrm{PhD}$ researcher in law at the European University Institute in Florence, Italy Stein.Brekke@eui.eu 
This research is funded by the Danish National Research Foundation Grant no. DNRF105.

iCourts - Centre of Excellence for International Courts - focuses on the ever-growing role of international courts, their place in a globalizing legal order, and their impact on politics and society at large. To understand these crucial and contemporary interplays of law, politics, and society, iCourts hosts a set of deeply integrated interdisciplinary research projects on the causes and consequences of the proliferation of international courts.

iCourts opened in March 2012. The centre is funded by a large grant from the Danish National Research Foundation (for the period 2012-18). 


\title{
That's an Order! \\ The Orders of the CJEU and the Effect of Article 99 RoP on Judicial Cooperation
}

\author{
Urška Šadl, Daniel Naurin, \\ Lucía López Zurita, Stein Arne Brekke
}

October 2020

\begin{abstract}
The benefits of timely justice and rigorous judicial argument are impossible to overstate and hard to reconcile. In its struggle to deliver both, the Court of Justice of the European Union has initiated several reforms of its procedures. The so-called adjudicating orders arguably achieve the impossible: They fast-track recurring questions while safeguarding legal coherence. The present article unpacks this premise. It shows that seemingly inconsequential procedural amendments, often overlooked by scholars, give the Court full control over relevant European legal problems, and centralize its power.

Concretely, the analysis introduces a typology of orders of the Court, to demonstrate the unique legal character of adjudicating orders. It then investigates their effects against the backdrop of manifold procedural reforms and institutional adjustments. The findings indicate that the greatest efficiency gains follow reforms, which the Court initiates and implements in relative anonymity. Moreover, the use of adjudicating orders increases in response to a sudden and considerable increase of legally similar preliminary references from one Member State. An equal increase of references from the courts of several Member States has no such effect. The findings suggest that the Court uses adjudicating orders to disengage from 'local' problems and unilaterally terminate the conversations with resolute national courts. Thereby, the preliminary reference procedure, envisaged and promoted as a collaborative tool, transforms into a centralized mechanism of speedy and authoritative dispute resolution.
\end{abstract}

\section{Introduction: The Judicial Dilemma}

The Court of Justice of the European Union (the Court), arguably the world's most powerful international court (Alter, 2009; Martinsen, 2015; Kelemen, 2016; 
Stone Sweet, 2004), stands powerless before its fast filling docket. ${ }^{1}$ Or does it? This article investigates how the Court organizes its procedures to manage the increasing caseload and how this affects the relationship with its closest judicial interlocutors: The national courts. The relationship is framed in Article 267 of the Treaty (TFEU), which states that national courts can (and sometimes must) refer questions of interpretation and validity of European Union law to the Court. The mechanism is known as the preliminary reference procedure. Literature suggests that it nurtures a constructive dialogue with national courts. The latter underwrites institutional legitimacy, fosters uniform application of European Union law, and guarantees the protection of rights of millions of European citizens (Bobek, 2013; Lecourt, 1976; Weiler, 2001; Pescatore, 2010). In practice, the mechanism has slowly gained popularity, generating a rich and diverse jurisprudence. On the flip side, it has overwhelmed the dockets in Luxembourg, and contributed to unwelcome delays in the Court's handling of cases.

In the light of the potential and the looming pitfalls, the functioning of Article 267 TFEU on the ground, regulated in the Court's Rules of Procedures $(\mathrm{RoP})$, and shaped by the Court's own practices, becomes of utmost relevance (Lasok, 2017; Lenaerts et al., 2014; O'Leary, 2002; Dunoff and Pollack, 20182019). The Court, clearly aware of both, has initiated several reforms of its RoP, with a goal to deliver timely justice of high standard (Skouris, 2006). Adjudicating orders (AOs) are a procedural innovation, which strikes the optimal balance between efficiency and quality. According to Article 99 of the RoP, the Court can reply to the question of the national referring court with an AO, when the question of interpretation and validity of European Union law is identical to a question on which the Court has already ruled, where the reply to such a question may be clearly deduced from existing case law or where the answer to the question referred for a preliminary ruling is beyond reasonable doubt. The referring courts receive a reasoned reply, stating that the Court has already answered their questions in a previous judgment, or developed a rich and clear jurisprudence on the topic. Since 2003, the Court can do so following the proposal of the Reporting Judge and after hearing the Advocate General. Notably, it can dispense with the submissions of the parties, the written opinion of the Advocate General and the oral hearing.

By legal standards, AOs are a unicum: Orders by name but fully fledged judgments in substance. The simplified and faster procedures, designed to process the cases via AOs, save time. The reasoned parts uphold the Court's commitment to uniform application. The solution sounds almost too good to be true, calling for further analysis of its nature and effects.

To this end, the article situates AOs in the context of judicial proceedings and establishes a typology of Court's orders. Orders are official decisions, which document and govern each step of the proceedings: From the moment when the claim is filed to the moment when the Court issues a final decision in the case. The Court uses two types of orders: Procedural and reasoned orders. With

\footnotetext{
${ }^{1}$ The Court itself expresses these concerns on an annual basis in its yearly reports, see for example CJEU, 2019, p. 25; CJEU, 2018, p. 58.
} 
procedural orders, the Court sets the date of an oral hearing, designates the number of judges that will hear the case, or removes a case from the docket. With reasoned orders, the Court decides that it does not have the jurisdiction to hear a case, or that an appeal is manifestly unfounded or inadmissible. The difference between reasoned and procedural orders is that in the latter, the Court must justify its decision. The instances in which the the Court can or must issue any type of order, are regulated in the Court's RoP. Those play a critical role in the administration of justice. AOs are reasoned orders.

The article moreover links the use of AOs to a series of amendments to the Court's RoP taking place over 30 years. Importantly, it demonstrates that the Court was driving several reforms since the introduction of AOs in RoP following their Amendment in 1991.

The analysis draws on a unique dataset of all orders published by the Court since it issued its first order in 1955, that is, over 4500 orders. ${ }^{2}$ It is the first systematic empirical analysis of the frequency and categories of the Court's orders.

We find that the Court, since the 2000 reform of the RoP, solves between 5 and 10 percent of the preliminary reference cases with AOs. The probability that the Court will decide a case with an $\mathrm{AO}$ increases when the number of references rises sharply in a specific policy area. Moreover, the Court is particularly likely to decide by means of an AO rather than a judgement when many similar cases arrive from the same Member State over limited time. By contrast, numerous references concerning the same legal provision across Member States do not result in a higher probability of AOs. To illustrate, a spike of references concerning consumer protection after the 2008 financial crisis prompted a significant rise of AOs. A closer inspection of references reveals that most originated from the disputes in a handful of Member States and strongly reflected their local background. The infamous abusive clauses in mortgage contracts in Spain are a case in point (see the saga following the decision of the Court in case C-415/11, Aziz).

This means that by resorting to AO, the Court signals its lack of interest in the debate while trying to maintain its legitimacy among Member States. By implications, it introduces a vertical dimension to an otherwise horizontal judicial dialogue, even when the relative number of $\mathrm{AO}$ remains limited. AOs open a considerable maneuvering space for the Court to dictate the terms of the preliminary reference procedure unilaterally. Importantly, they do so under the table.The Court becomes the sole arbiter of questions and issues that are of European legal significance. Such transformation challenges the publicly upheld image of a collaborative and heterarchical dialogue between European courts.

Our analysis contributes to the existing literature in two ways. First, it demonstrates that AOs, and possibly other types of orders, are more than a matter of good housekeeping, and present a valuable resource for the analysis of judicial behavior. Second, the findings highlight the relevance of procedural

\footnotetext{
${ }^{2}$ The data presented in this paper was obtained from the CJEU Database Platform (Brekke et al., n.d.).
} 
forms and routines, regulated in the Court's internal RoP, which produce sizeable external effects: They centralize judicial power in Luxembourg, a matter often overlooked.

The article is divided in six sections. Section 2 maps all orders of the Court into a comprehensive typology. The typology demonstrates that AOs are legally unique, and distinct from similar types of Court's orders. As a distinct object of inquiry, they merit separate analysis. Section 3 details the development of AOs. Its aim is to relate the Court's struggle for efficient handling of its caseload to the introduction and transformation of AO. Section 4 outlines the hypotheses, describes the research design and presents the findings. Section 5 discusses the findings - in particular the effects of minor and anonymous reforms of the RoP on the distribution of judicial power and the character of judicial cooperation. Section 6 concludes and outlines promising avenues for further research.

\section{A Comprehensive Map of Court Orders}

The Court issues a variety of orders for numerous purposes in every case, which it decides. Those orders have never been counted nor classified, leaving an important part of the Court's decision making entirely unexplored. This section introduces a simple classification along two key dimensions: The competent authority that issues an order (the signatory) and the function of the order in the procedure. ${ }^{3}$

The first defining dimension of orders is the signatory. Orders can be issued by the President of the Court (the President), the Vice President, the Presidents of the Chamber, or the Court. The President can decide with an order in a number of scenarios, a power she can delegate to other judges. ${ }^{4}$ For example, the President can order to join one or more cases, ${ }^{5}$ or grant an injunction until the Court decides the case. ${ }^{6}$ Since 2012, orders from the President have become scarcer, as they are more commonly issued by the Vice President of the Court. Most orders are issued by the chambers of the Court, acting on behalf of the full Court. Orders of the Court, broadly speaking, vary greatly in their content and functions in the procedure. For instance, the Court may order not to hear the case, declare an appeal manifestly unfounded ${ }^{7}$, allocate the costs, ${ }^{8}$ grant legal aid, ${ }^{9}$ or request additional documents from the parties. ${ }^{10}$ Like judgments, orders issued by the Court are drafted in the chambers of individual judges.

\footnotetext{
${ }^{3}$ The existing attempts to provide an overview do not categorize orders by type. They record instances in which the RoP require a decision in the form of an order Barents (2016). Alternatively, they introduce a distinction between procedural and administrative orders without, however, relate the distinction to the Court's orders and judgments Lasok (2017)

${ }^{4}$ Similarly, the President of a Chamber might delegate the issuing of orders to a judge of the Chamber, who will then act, for those purposes, as President of the Chamber.

${ }^{5}$ Article 52 RoP.

${ }^{6}$ Articles 131, 162-163 RoP, 2012.

${ }^{7}$ Article 181 RoP, 2012.

${ }^{8}$ Articles 138-139, RoP, 2012.

${ }^{9}$ Article 116 RoP for the preliminary ruling and 184 RoP for direct actions.

${ }^{10}$ Article 62 RoP, 2012.
} 
The second key dimension of the classification is the content, meaning the legal substance, which the order decides on. ${ }^{11}$ This makes for the most elementary distinction between procedural orders and reasoned orders. Procedural orders primarily organize the steps of the procedure, including the internal management or administration of the Court. Reasoned orders touch upon the substance (the legal content) of a case. That said, a single order can serve multiple purposes, combining reasoned and procedural elements. The categories are not mutually exclusive. Hence, it is difficult to 'count' orders by type.

Procedural orders can be further divided into strictly procedural matters that organize the procedure (strictly procedural orders), like which Chamber will hear the case or whether to join cases, and orders of a more managerial nature (administrative orders). For instance, administrative orders determine when the Court will hold a hearing or whether to erase the case from the registry of the Court. ${ }^{12}$ In other words, procedural orders create a paper trail of judicial proceedings.

By contrast, reasoned orders can modify the procedural and substantive position of the parties. Reasoned orders can declare the appeal manifestly founded or unfounded, ${ }^{13}$ halt the proceedings, ${ }^{14}$ exclude a legal counsel from the procedure, ${ }^{15}$ allow the intervention of witnesses ${ }^{16}$ and rule whether the case is admissible. ${ }^{17}$ Crucially, reasoned orders in Article 99 RoP (former Article 104), or $\mathrm{AO}$, can be used to reply to preliminary questions.

AOs are unique. They are more akin to Court judgments. The Court can issue them in the procedure for a preliminary ruling (Article 267 TFEU) to reply to the national courts when the referred question meets one of three criteria: 1) it is identical to a question on which the Court has already ruled, 2) the reply to such a question may be clearly deduced from existing case-law, or 3) the answer to the question referred for a preliminary ruling admits of no reasonable doubt. The effects for the national court and European case law are identical to those of a judgment. The stated rationale of these orders is, unsurprisingly, efficiency: AOs are procedurally lighter than the judgments, even when compared to the judgments issued in a simplified procedure. Namely, before issuing a judgment, the Court will typically consider the submissions of the parties, the Opinion of the Advocate General and hold an oral hearing. These requirements are considerably modified for 'fast' (including expedited or urgent) procedures, in which the Court will nevertheless consider the submissions of the parties, hear the Advocate General without a written opinion and hold a hearing bar in exceptional cases. The judgment of the Court is always final. The decision of the Court in an $\mathrm{AO}$ is also final (adjudicative), but the procedural constraints for the Court differ significantly. In AOs the Court will not consider

\footnotetext{
${ }^{11}$ For something slightly similar, but speaking generally of decisions and not orders, see Lasok (2017).

12 Article 100, RoP, 2012.

${ }^{13}$ Articles 181-182 RoP.

${ }^{14}$ Article 150 RoP.

${ }^{15}$ Article 46(2) RoP.

${ }^{16}$ Article 66 RoP.

${ }^{17}$ Article 53(2) RoP.
} 
the submissions of the parties, hear the Advocate General only informally (the Advocate General will not produce a written opinion in the case) and dispense with the oral hearing. ${ }^{18}$ These lax procedural requests are valid for all orders. However, procedural orders are not final and do not adjudicate on the substance of the case, nor do they change the procedural position of the parties. AOs, by contrast, are judgments in the shape of an order. ${ }^{19}$

Table 1 provides and overview of the procedural requirements for judgments and orders. Procedures, represented in the columns from left to right, are classified according to a series of procedural requirements, listed in the first column from the left. Those constraints involve the signatory (the authority, which issues the order), the requirements, imposed by the RoP, the stage, in which the order is issued, and the function of the order. For instance, administrative orders (first column from the right) are issued by a chamber of the Court, without a hearing or participation of the Advocate General, and do not end the proceedings: They are organizational documents par excellence. The second row indicates the main classification of judgments and orders. Judgments are divided into those issued in the ordinary procedure, and those issued in the 'fast procedure', which imposes fewer procedural constraints. For instance, as indicated in the seventh row, a 'fast procedure' requires only the hearing of the Advocate General, but not a written opinion. The orders are grouped into reasoned and procedural orders (second row, five columns from the right), and further classified into subtypes (third row, five columns from the right).

\section{The Quasi-Secret History of Adjudicating Or- ders}

While frequent and central since the 1950 s, orders do not provide a straightforward record of the procedural history of the Court. Two reasons account for that: On the one hand, the functions, which Court orders can serve, have substantially evolved over time. On the other hand, the Court's practice of publishing procedural orders has changed. The publicly available sources do not always reveal whether the Court issued an order without publishing it or did not issue an order at all. The analysis considers all published orders of the Court.

Figure 1 shows the relative number of procedural, reasoned, and administrative orders issued by the Court each year since 1970. The numbers reported

\footnotetext{
${ }^{19}$ See the internal guidelines of the Court (Guide Pratique, version of 2013) at paras. 15-16. There is however a lot of variation in the procedural treatment of AOs. Whereas the rule seems to be that submissions are not necessary, it is also frequent that the different parties intervene in the proceedings leading to an AO. In some exceptional cases, the proceedings are identical to those leading to a regular judgment. For instance, see Case C-92/16, Bankia SA v Henry-Rodolfo Rengifo Jiménez and Sheyla-Jeanneth Felix Caiza, ECLI:EU:2019:560. The case, a Spanish reference on unfair terms in mortgage contracts, was decided by an AO after an oral hearing with the interventions of the parties in the main proceedings, the Spanish State, three other Member States and the European Commission. Even the Advocate General delivered an Opinion on the case (Opinion of Advocate General Szpunar in case C-92/16).
} 


\begin{tabular}{|c|c|c|c|c|c|c|}
\hline & \multirow{2}{*}{\multicolumn{2}{|c|}{ Judgments }} & \multicolumn{4}{|c|}{ Orders } \\
\hline & & & \multicolumn{2}{|c|}{ Reasoned orders } & \multicolumn{2}{|c|}{ Procedural orders } \\
\hline & Normal & Fast & Adjudicating & Other & Procedural & Administrative \\
\hline Signatory & $\begin{array}{l}\text { Chamber or } \\
\text { Court }\end{array}$ & $\begin{array}{l}\text { Chamber or } \\
\text { Court }\end{array}$ & $\begin{array}{l}\text { Chamber or } \\
\text { Court }\end{array}$ & $\begin{array}{l}\text { Chamber or } \\
\text { Court }\end{array}$ & $\begin{array}{l}\text { Chamber, } \\
\text { Court or } \\
\text { President }\end{array}$ & $\begin{array}{l}\text { Chamber or } \\
\text { Court }\end{array}$ \\
\hline $\begin{array}{r}\text { Submissions of } \\
\text { parties }\end{array}$ & $\begin{array}{l}\text { Yes, no } \\
\text { restrictions }\end{array}$ & $\begin{array}{l}\text { Yes, no } \\
\text { restrictions }\end{array}$ & $\begin{array}{l}\text { Yes (not } \\
\text { knowing about } \\
\text { reasoned } \\
\text { order) }\end{array}$ & $\begin{array}{l}\text { Yes (limited to } \\
\text { decision by } \\
\text { reasoned } \\
\text { order) }\end{array}$ & $\begin{array}{l}\text { No (w/ } \\
\text { exceptions) }\end{array}$ & No \\
\hline $\begin{array}{r}\text { Consult } \\
\text { National } \\
\text { Court }\end{array}$ & No & No & $\begin{array}{l}\text { No (but } \\
\text { mandatory } \\
\text { before 2006) }\end{array}$ & No & No & No \\
\hline $\begin{array}{l}\text { Opinion or } \\
\text { Hearing AG }\end{array}$ & Opinion & Hearing & Hearing & Hearing & $\begin{array}{l}\text { No }(\mathrm{w} / \\
\text { exceptions) }\end{array}$ & No \\
\hline Oral hearing & Yes & $\begin{array}{l}\text { Yes, unless } \\
\text { decided } \\
\text { otherwise }\end{array}$ & No & No & No & No \\
\hline $\begin{array}{r}\text { Stage of } \\
\text { proceedings }\end{array}$ & $\begin{array}{l}\text { End of } \\
\text { proceedings }\end{array}$ & $\begin{array}{l}\text { End of } \\
\text { proceedings }\end{array}$ & $\begin{array}{l}\text { End of } \\
\text { proceedings }\end{array}$ & $\begin{array}{l}\text { During } \\
\text { proceedings } \\
\text { (exceptions) }\end{array}$ & $\begin{array}{l}\text { During } \\
\text { proceedings }\end{array}$ & $\begin{array}{l}\text { Prior or after } \\
\text { proceedings }\end{array}$ \\
\hline $\begin{array}{l}\text { Function in } \\
\text { the procedure }\end{array}$ & $\begin{array}{l}\text { Final decision } \\
\text { on the case }\end{array}$ & $\begin{array}{l}\text { Final decision } \\
\text { on the case }\end{array}$ & $\begin{array}{l}\text { Final decision } \\
\text { on the case }\end{array}$ & $\begin{array}{l}\text { Organize } \\
\text { procedure } \\
\text { (exceptions) }\end{array}$ & $\begin{array}{l}\text { Ordering the } \\
\text { different } \\
\text { stages of the } \\
\text { procedure }\end{array}$ & $\begin{array}{l}\text { Organization } \\
\text { of the Court }\end{array}$ \\
\hline
\end{tabular}

Table 1: The features of the different types of judgments and orders. A 'fast judgment' dispenses with the written Opinion of the Advocate General, following Article 20(5) of the Statute of the Court. The table presents the common features to the different types, though exceptions are possible. Procedural orders might be issued after hearing the parties and or the Advocate General in the case (ie: stay of the proceedings until a case is solved in Article $55 \mathrm{RoP}$ ). Finally, other type of reasoned orders might end the proceedings and entail a final decision on the case (for all, see article $181 \mathrm{RoP}$ on manifestly unfounded appeals. A reasoned order in that case finalizes the appeal). 


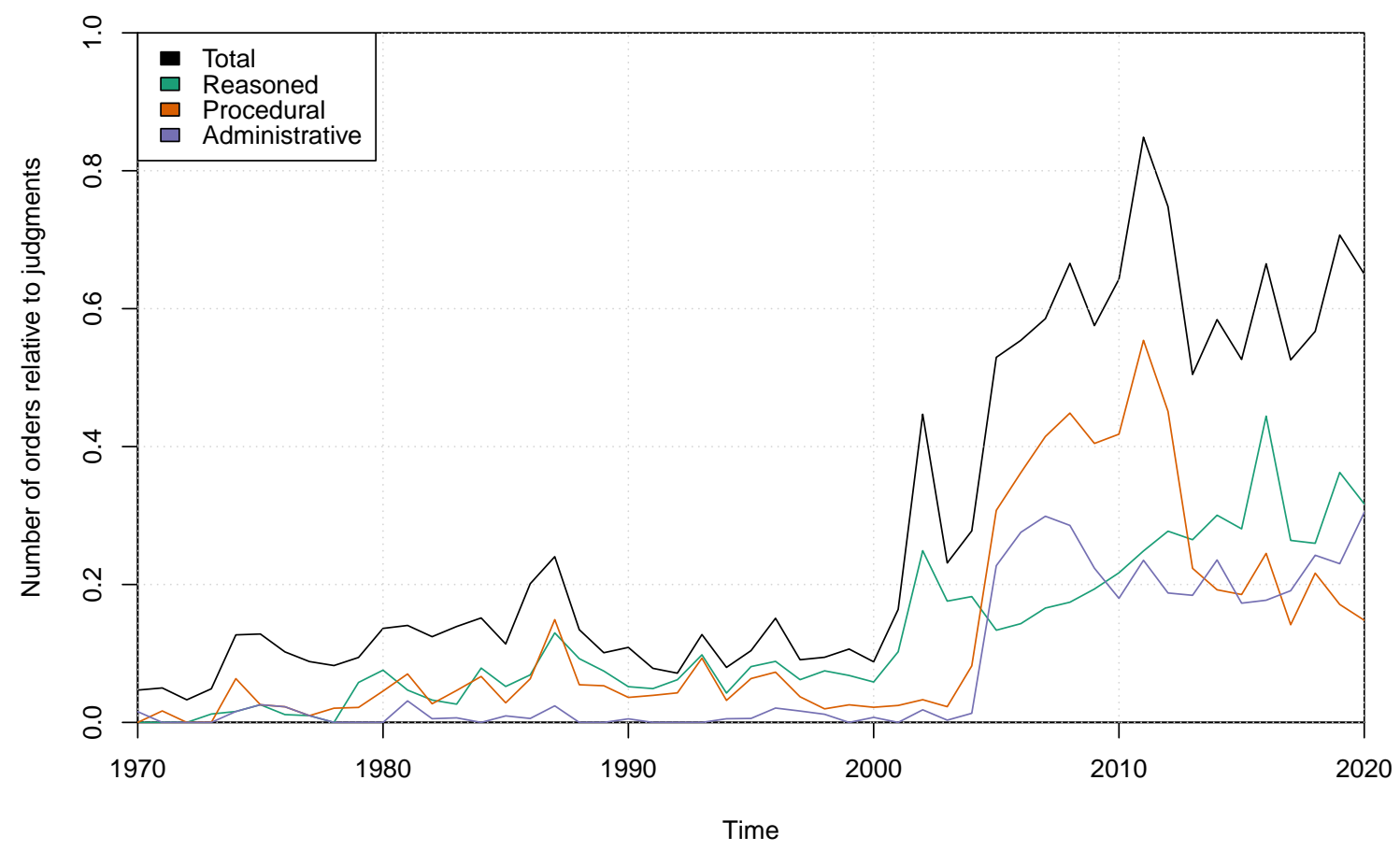

Figure 1: While the Court has been publishing orders since the 1950s, the relative use - or publication - of Court orders has increased dramatically the last 20 years. Only the period since 1970 is included in the figure, as the low number of both judgments and orders in earlier years makes relative numbers unreliable.

are relative to the total number of judgments published by the Court: A value of 0.5 indicates that one order was published for every two judgments in the given year. As the different types of orders are not mutually exclusive, the sum of the three order types is greater than the total. The relative increase in the publication of Court's orders comes in addition to a strong absolute growth: While only three published orders are on record for 1970, more than 300 orders were published in 2019. Of these, less than 50 were AOs.

AOs were introduced in 1991 in Article 104 to the RoP in a restricted format: The Court could only reply to a preliminary reference by an $\mathrm{AO}$ if the referred question was identical to a question which the Court had dealt with in a previous judgment. Thus, the use of these orders remained limited until a later amendment of the RoP, which extended the Court's discretion to issue AO. From 2000, the Court could issue them in cases where the answer to the question could be clearly deduced from the existing case-law or where the question admitted no reasonable doubt. ${ }^{20}$

${ }^{20}$ Amendments to the Rules of Procedure of the Court of Justice of the European Com- 
Strikingly, the 2000 reform is often overlooked when discussing procedural developments at the Court. It directly addressed a demand of the Court in its Annual Report for 1999: ${ }^{21}$ Simplified proceedings, including an expansion of Article 104(3) needed to be urgently adopted to face 'the structural increase in the number of pending cases'. ${ }^{22}$

The increase in the use of AOs following the 2000 reform of the RoP was rapid and points to the fact that the Court was ready to quickly implement its own procedural solutions. Indeed, within a year after the amendment, the Court decided seven per cent of all preliminary references by an AO. The procedural constraints nonetheless remained tight for each of the three scenarios. As the Court had to inform the national court and hear the parties and the Advocate General, AOs did not save the Court much time.

Figure 2 presents the number of AOs issued per year, relative to all yearly decisions in preliminary reference procedures. Even if the relative number of orders appears stable, the increasing case load of the Court means there has been an absolute growth: from 20 AOs published in in 2002 to 45 in 2019.

By 2003, the Court was grappling with a growing number of unsolved preliminary references, ${ }^{23}$ and fearing that the accession of ten new Member States planned for 2004 would only magnify the existing problems. In this context, the Court rethought the handling of preliminary references (Skouris, 2006). ${ }^{24}$ President Skouris suggested that: 'The referring judge should also be prepared to receive more rapid but simplified answers. As a consequence of the development of the case-law, the Court will most probably be in a position to respond more often to certain requests for a preliminary ruling by way of a simple order adopted on the basis of Article 104, paragraph 3 of its RoP, referring to previous judgements or relevant case-law' (ibid.). This led to a major overhaul of Article 104 in 2005: ${ }^{25}$ The Court no longer had to consult the national court of its intention to reply by $\mathrm{AO}$ or hear the parties. The obligation remained in cases "where the answer to the question referred to the Court for a preliminary ruling admits of no reasonable doubt ${ }^{26}$. This key reform of reasoned orders responds to a great extent to the structural changes introduced by the Treaty of Nice. The latter substantially simplified the procedure for the amendment of the instruments regulating the Courts. The RoP could be amended on the proposal of the Court and approved by the Council. The Court gained considerable power to shape the procedures and its working methods (ibid.).

After the amendments in 2012, Article 104 RoP became Article 99 RoP,

munities of 16 May 2000 (OJ L 122 of 24.5.2000, p. 43).

21 'The Future of the Judicial System of the European Union. Proposals and Reflections', Report of the Court of Justice of the European Union, 1999.

${ }^{22}$ See Report at Chapter 2, Section 2 iii).

${ }^{23}$ The Court's backlog almost doubled between 1993 and 2003, amounting to around 350 unanswered references in January 2003.

${ }^{24}$ It was clear that the main problem were the many pending preliminary references and the difficulties attached to processing them.

${ }^{25}$ Amendments to the Rules of Procedure of the Court of Justice of the European Communities of 12 July 2005 (OJ L 203 of 4.8.2005, p. 19).

${ }^{26}$ Article 104(4) RoP, 1991. 


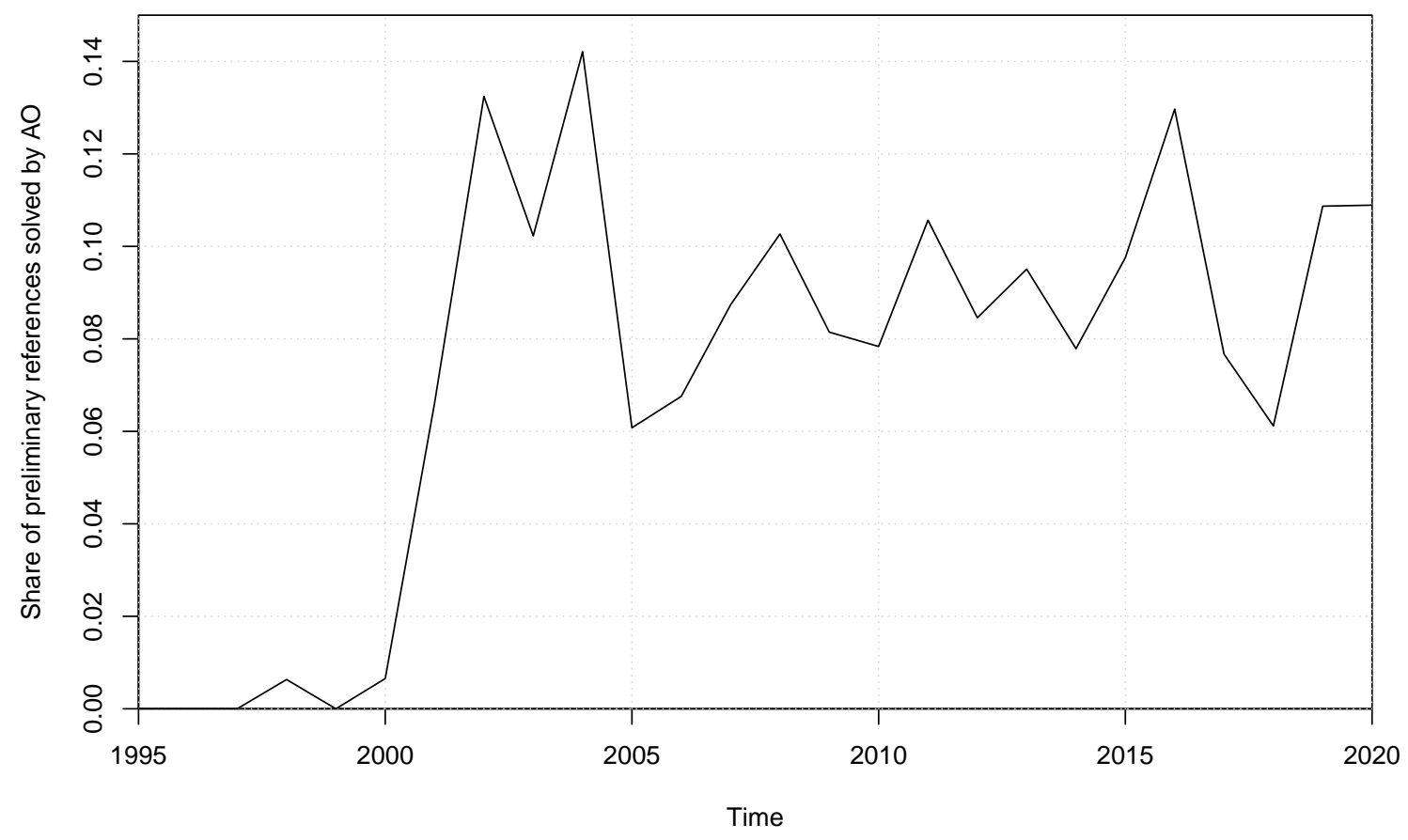

Figure 2: The development in the share of preliminary references answered by an adjudicating order. Even if there is relative stability in this development, there was also an absolute growth in the number of preliminary rulings in the same period, leading to a growth in the absolute number of AOs.

and the Court could issue an $\mathrm{AO}$ without consulting the parties or the national courts. The obligation to consult the Advocate General remained in place.

While the 2000 amendment to the RoP had a defining impact on the Court's use of AOs, no such trend follows the 2005 and 2012 amendments, as illustrated in Figure 2. The reforms of 2005 and 2012 did not affect the number of issued AOs. However, the amendments significantly shortened the processing time of $\mathrm{AO}$, measured as the number of days between the lodging of the case and the time of the final decision.

Figure 3 shows the procedure times of AOs relative to the average time needed to issue the judgments, cited by those orders. ${ }^{27}$ The comparison between orders and cited judgments follows the logic of Article 99 RoP: First, that AOs and the relevant existing judgments decide on the merits of the case; and second, that AOs closely resemble the judgments that they cite. Citations in AOs thus accurately reflect which case-law the Court assumes is 'settled'. The comparison moreover excludes the effect of case complexity and is consistent with the typo-

\footnotetext{
${ }^{27}$ In order to control for changing efficiency over time, all processing times are measured to be relative to the yearly average procedure time of judgments.
} 
logy presented in the beginning of this section. The results indicate a sizeable efficiency gain of the reform of 2005: Almost overnight, the Court issued several $\mathrm{AO}$ with processing time that was over 500 days shorter compared to that of judgments. Such reduction had only been observed once in the years prior to the 2005 reform. Moreover, figure 3 shows that the trend of substantially shorter processing time (over a year shorter than those of judgments) continued, though relative efficiency gains appear to have declined since 2012 .

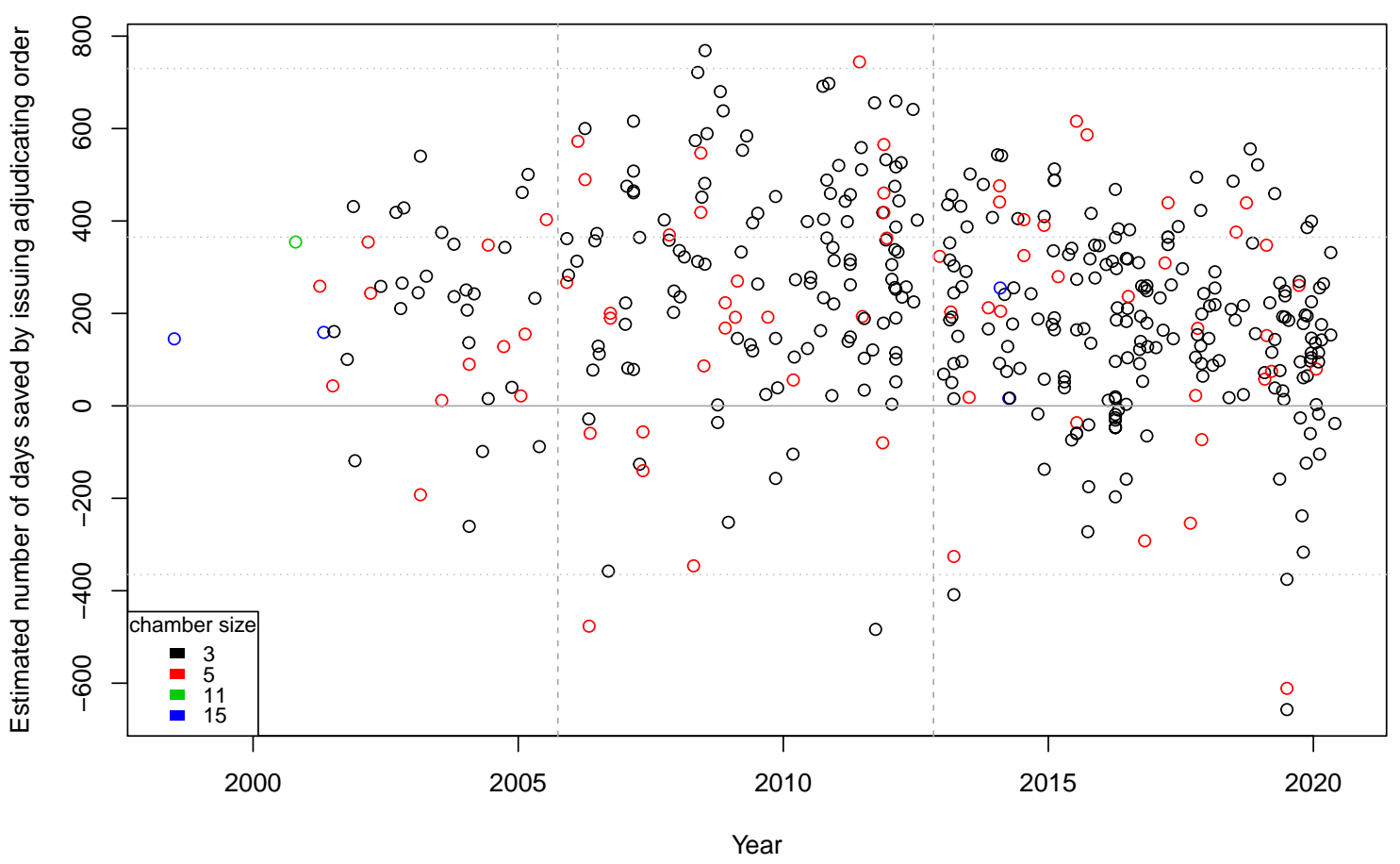

Figure 3: The procedure time of AOs compared to the procedure time of the judgments they cite, in days. Each data point represents an order. A value of 100 on the $\mathrm{Y}$ axis indicates that the procedure time of the given order was 100 days shorter than the average procedure time of the judgments it cited. In case of negative values, the Court spent more time issuing the AO than it spent on the judgments it was citing. Colours indicate Chamber size (a three or five judge chamber, and a Grand Chamber (between 11 and 15 sitting judges). Vertical lines indicate changes in the RoP, horizontal lines mark time in years.

AOs seem to have substantially reduced the number of days needed to reach a final decision in a case. While the procedural modifications in 2000 turned into an absolute increase in the numbers of AOs issued, the progressive reduction of procedural constraints in 2005 until the current drafting of Article 99 RoP substantially increased the efficiency of the Court's decision making. 


\section{Analysis}

AOs are a near perfect substitute to judgments. They are judgments in substance, but far less taxing in terms of the Court's resources. Importantly, while the Court has the option to respond by an $\mathrm{AO}$ when the preliminary reference meets Article $99 \mathrm{RoP}$ criteria, it is never under an obligation to do so. In other words, the Court can choose to reply to preliminary questions with an AO. It might decide to reply with an AO for non-legal (strategic) reasons, like efficiency, the wish to neutralize persistent questioning, or dodge further discussion initiated by individual national courts. It is not unthinkable that the Court would use AOs to selectively curb the activism of national judges.

The Section presents 1) a set of empirically testable hypotheses, 2) a novel framework for testing these hypotheses against an empirical background of the Court's references for preliminary rulings since the amendments of the RoP in 2000 and 3) the results.

\subsection{Hypotheses}

Literature points at difficulties in determining why and when the Court replies with an AO (M. Broberg, 2008). In principle, the Court should only reply with an $\mathrm{AO}$ when the case referred is legally beyond doubt. The Court has full discretion to decide to use AOs, and it is thinkable that it might do so where the questions referred are not beyond legal doubt. Literature suggests that AOs might be a filtering mechanism (Tridimas, 2003), allowing the Court to choose which precedents it wishes to revisit (ibid.). If, alternatively, AOs are primarily a means of docket control, the use of AOs should increase when the Court is confronted with an increased caseload. A structural increase of cases triggers the need to control the docket. Thus, the Court is expected to use AOs more often in those areas of European Union law that attract more preliminary references (i.e. areas with more cases). Hence:

$\mathbf{H}_{\mathbf{1}}$ Relatively high number of preliminary references in a policy area increases the probability that the Court will respond with an $A O$.

Second, preliminary rulings of the Court are sui generis judgments: They do not directly decide a dispute, but establish what a provision of EU law means. After the Court has clarified the meaning, subsequent preliminary questions will less likely raise new points of law. Hence, the Court would be more likely to issue an $\mathrm{AO}$ when the questions referred closely resembled solved problems. The existing judgments, interpreting the provisions that are the subject of the preliminary questions referred by the national court, will thus more likely provide an answer, justifying the use of AOs. This leads to hypothesis 2:

$\mathbf{H}_{2}$ The likelihood of an $A O$ increases when the referred question concerns a provision that is a frequently a subject of references for preliminary rulings. 
An even stronger resemblance to past case law can be assumed when the national court is not only asking about the same provisions that have been the subject of previous preliminary rulings, but when these previous rulings also originated from the courts in the same Member State. In this context, the Court might have two alternative incentives to respond with an $\mathrm{AO}$ in lieu of a judgment. First, the legal issues are likely to be highly similar, reducing even further the possibility that each additional preliminary question raises new points of law. Second, and crucially, the Court might seek to deter a court from a Member State from referring more cases on the same topic: AOs can signal a rebuttal of the question of the national court (Karin Leijon and Monika Glavina, 2020). This national dimension leads to hypothesis 3 :

\section{$\mathbf{H}_{3}$ The Court is more likely to issue an $A O$ when similar preliminary questions are referred from the same Member State rather than from different Member States.}

These hypotheses will be tested empirically below, against a data set including all decisions in preliminary reference procedure since the 2001 reform of the RoP.

\subsection{Research Design}

The hypotheses are tested by fitting a generalized linear model (GLM) estimating the probability of a preliminary reference ending in an AO (1) rather than a judgment (0). The statistical analysis applies to the data set including all preliminary reference procedures in subject matters with at least four observed years with at least ten decisions published, since the amendment of the RoP in May 2000. The analysis omits observations in which the questions are not clearly defined in the document. This leaves just short of 4000 documents, of which over 300 are AOs.

Hypothesis 1 is represented by two independent variables: 1) observed increase in litigation in a policy area over the last five years (change), and 2) the total number of decisions published in the policy area in a year (n_decisions). By including these two variables the model accounts for a high level of litigation and an observed increase of caseload. In addition, an interaction effect allows the number of decisions to mediate the effect of an increase in litigation. This effect is expected to be negative, as the increase of litigation is relative to the number of decisions; ie. an increase of five more cases per year is more significant in a policy area with ten cases per year than in a policy area with a hundred cases per year. Both variables derive from the Court's classification of policy areas, and are available on its official web portal (curia.europa.eu).

The analysis includes two further independent variables: one (repetition) for the number of preliminary questions related to the same legal provisions in the last five years $\left(\mathrm{H}_{2}\right)$, and another (repetition_nat) that provides a similar count including only preliminary references lodged by courts in the same Member State $\left(\mathrm{H}_{3}\right)$. These variables measure the repeated referral of questions relating to specific legal provisions. 
One recurring section in the preliminary rulings published by the Court of Justice consists of a short summary of the dispute at the national level and the preliminary questions referred by the national judge. Thus, it is possible to accurately identify the legal provisions mentioned by the national court. This section with a typical headline "the main proceedings and the question referred for a preliminary ruling' refers only to those. This means that the section accurately reflects the provisions cited by the national court. Finally, the section is easy to identify, as it is near identical in judgments and AOs, and lends itself well to comparison.

Figure 4 visualizes the relationship between the increase of references in a policy area and the existence of previous questions concerning the same legal provision (the left side of the figure) on the one hand, and the probability that the Court will decide with an $\mathrm{AO}$ on the other hand (the right side of the figure). The vertical arrows between the round brackets (left side of the figure) indicate that an increase of questions related to the same provision from the same Member State will lead to an increase of the number of previous questions and the number of Court decisions.

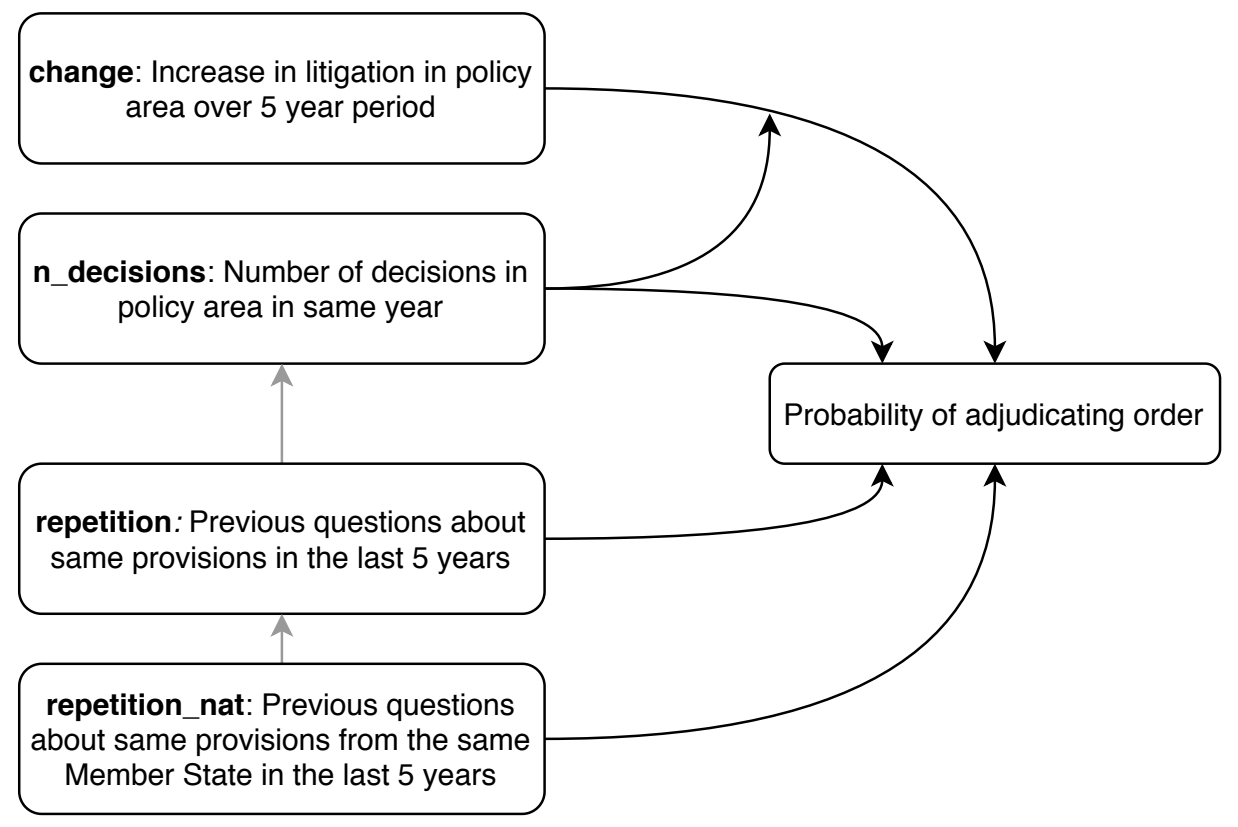

Figure 4: The figure illustrates the circumstances, which lead to AOs. The upper half of the figure relates to hypothesis 1 (docket control), while the lower half relates to hypothesis 2 (repetition) and 3 (repetition_nat)

The repetition variables - repetition and repetition_nat - are constructed by calculating a repetition score for each unique decision. The calculation follows the legal provisions cited by the national court. The legal provision is identified 
by analyzing the section of the Court's decision (judgment or AO) containing the short summary of the main proceedings and the referred questions, as explained above. Once identified, all instances of the same legal provisions mentioned by a national court over the past five years are counted. For instance, if the referring court refers to provision $\mathrm{x}$, and provision $\mathrm{x}$ was mentioned in three prior references in the past five years, the repetition score is 3 . If the national court cites provisions $\mathrm{w}, \mathrm{y}$ and $\mathrm{z}$ in the preliminary reference, which have been mentioned in the past five years 10,2 , and 0 times, the repetition score is $\frac{10+2+0}{3}=4$. The calculation of the repetition score for the Member State (repetition_nat) includes only the preliminary references originating in that Member State.

Repetition scores are log transformed to keep extreme observations from driving the results. All independent variables are scaled to have a mean of zero, and a value of one representing one standard deviation from the mean. This makes the strength of the estimated effects directly comparable across variables.

\subsection{Results}

The findings of the model discussed above largely confirm hypotheses 1 and 3 , while providing no support for hypothesis 2 . An increase in the number of cases in a policy area (change) is associated with a higher probability that the Court will respond by an AO. This indicates that the Court uses AOs to shorten the processing time when the cases in a policy area suddenly pile up. As expected, the effect of change is relative to the total number of decisions, with a negative interaction term with n_decisions.

\begin{tabular}{r|rrrrl} 
& Estimate & Std. Error & $\mathrm{t}$ value & $\mathrm{p}$ value & \\
\hline (Intercept) & 0.0745 & 0.0043 & 17.2613 & 0.0000 & $* * *$ \\
repetition & -0.0008 & 0.0057 & -0.1353 & 0.8923 & \\
repetition_nat & 0.0251 & 0.0057 & 4.4142 & 0.0000 & $* * *$ \\
n_decisions & 0.0077 & 0.0042 & 1.8464 & 0.0649 &. \\
change & 0.0110 & 0.0045 & 2.4476 & 0.0144 & $*$ \\
n_decisions:change & -0.0121 & 0.0030 & -3.9661 & 0.0001 & $* * *$
\end{tabular}

Table 2: Result from generalized regression model predicting outcome by adjudicating order. One star $(*)$ indicates a $\mathrm{p}$ value of $p<.05$, three stars $(* * *)$ a value of $p<.001$.

In support of hypothesis 3, the repetition of legal provisions mentioned in prior references of the Courts of the same Member State is the strongest indication that the Court will respond with an AO (repetition_nat). With a level of national repetition one standard deviation above average, the probability of an $\mathrm{AO}$ increases by 2.5 percentage points. This might seem insignificant, however, it is crucial to note that less than eight percent of preliminary rulings are solved 
by an $\mathrm{AO}$. In relative terms, a change in likelihood of 2.5 percentage points is substantial. There is no indication that repeated references concerning the same legal provision across Member States increase the likelihood of AOs. The finding is striking because the existing judgments and AOs interpreting that legal provision would have most likely settled the law independently of the geographic origin of preliminary references. ${ }^{28}$

The strong Member State specific effect and the non-existing cross-Member State effect can be interpreted in two ways: 1) questions regarding the same legal provisions originating from other Member States are almost never comparable enough for the Court to draw clear parallels and apply Article 99 RoP; or 2) the Court issues AOs as a signal to national courts to stop submitting questions regarding a specific issue. The latter explanation is interesting as the decisive factor would not be in the legal merits of the reference, but rather related to the Member State where the preliminary question originated. If only repetition was decisive for the decision to reply with an AO, it would be reasonable to see at least a weak cross-Member State effect as well.

\section{Discussion: It Was too Good to be True}

The history of AOs is in large part a story of judicial control and institutional self-empowerment. The analysis suggests first, that the Court has used AOs to extinguish sudden eruptions of caseload, and second, to bring in line resolute referring courts. Finally, the Court calibrated its procedures to achieve these ends without the scrutiny of political institutions. The practice has important implications for judicial cooperation and the development of European Union law.

The temporal analysis of AOs shows an uneven impact of procedural reforms. While the RoP introduced the possibility of AOs in 1991, the Court started using them more frequently after the reform of 2000. Until then, the Court issued only one AO, involving the Grand Chamber (figure 3). The relative increase after 2000 was remarkable (figure 2). Surprisingly, the amendments in 2005 and 2012, minor but legally important, did not have the same effect. The amendments of 2005 considerably relaxed time consuming procedural constraints; the Court no longer had to inform the national court about its intention to decide with an AO nor hear the parties. An immediate increase of the frequency of AOs, which never materialized, would have seemed most logical.

The amendments in 2005 nonetheless considerably shortened the time of proceedings leading to an $\mathrm{AO}$ when compared to similar judgments (illustrated in figure 3). This resonates with the reshaping of the wider legal framework: the Treaty of Nice (2003) and the accession of the ten new Member States (2004). ${ }^{29}$

\footnotetext{
${ }^{28}$ Potentially, the effect of repetition could be obscured because of a strong counter influence of legal complexity. Even if this should be the case, it is noteworthy that the effect of non-Member State specific repetition is, unlike other variables, too weak to counter this (unobserved) effect.

${ }^{29}$ The Member States signed the Treaty of Nice in 2001, which came into force in 2003.
} 
The Court was finally in a position to implement its version of procedural efficiency and the idea of judicial cooperation in the expanding Europe, mindful of its own needs. ${ }^{30}$

The Court anticipated a new mode of cooperation. Its president envisaged a 'slight shift in the dialogue' that would require an increased 'knowledge and awareness in terms of European law' (Skouris, 2006). The vision was a nudge to the national courts to 'draft better references' and explain why the Court should revisit its case-law (Tridimas, 2003). The potential of AOs as a filtering mechanism of legally relevant questions, allowing the Court to decide which precedents to reconsider and when, is obvious (ibid.).

The findings of the analysis directly relate to the changing vision of judicial cooperation in Europe. Hypothesis 1 predicts that AOs are a means of docket control, especially when the number of cases in one policy area suddenly increases. The empirical analysis confirms that spikes within a policy area increase the probability that the Court will decide with an AO. The effect is present regardless of the previous questions concerning the same legal provision (i.e. when controlling for the previous questions on the same provision).

The empirical analysis does not support hypothesis 2. The number of AOs does not increase when questions referred for the preliminary ruling concern the legal provisions interpreted in prior preliminary rulings.

However, as predicted by hypothesis 3 , the Court is substantially more likely to decide with an $\mathrm{AO}$ when past references originate in the same Member State. By contrast, cross-national repetition does not lead to an increased use of AOs.

There are two competing explanations. First, the increase could be due to the great variation of the questions concerning the same legal provisions between Member States, and their greater resemblance when originating from the same Member State. This seems unlikely, as one could reasonably expect that courts situated in different Member States at least occasionally encountered very similar problems of interpretation of common rules. Second, the Court issues AOs for reasons other than the ones stated in Article $99 \mathrm{RoP}$. The context of the dispute, especially its 'pan-European' scope, seems to determine the Court's response.

The second explanation is more convincing in light of the observed bouts of litigation, localized in one or a handful of Member States. The disputes usually emerge in one policy area and involve a single legal provision (or rule), which suddenly becomes highly relevant for the solution of a pressing socio-economic conflict.

An example is the consumer protection litigation that ensued from the $2007 / 2008$ financial crisis. The national courts increasingly turned to the Court to attenuate the economic devastation and the plight of individual homeowners. Most preliminary references reached Luxembourg from Spain, Romania, Bulgaria and Slovakia. Nearly all focused on the interpretation of the unfair clauses in mortgage loans, concluded by consumers and banks. ${ }^{31}$. Once the

\footnotetext{
${ }^{30}$ President Skouris seems to confirm this view in 'Self-Conception, Challenges and Perspectives of the EU Courts' (2006).

${ }^{31}$ Most disputes referred to the interpretation of Council Directive 93/13/ECC of 5 April
} 
Court rather sympathetically interpreted the unfair terms clause of the Council Directive 93/13/EEC, AOs became a frequent means to dispose of the incoming preliminary references.

Criticizing the Court for trying to curb the activism of national judges or refusing to fuel their national reformist agendas would seem unfair. It would be equally difficult to object to its lack of enthusiasm to intervene in national disputes, especially when they are highly politicized or polarizing (as was the case in Spain, e.g. the Aziz saga, see Sánchez, 2014; ERLP, 2014). Regardless of the Court's intentions, however, AOs cut the ongoing conversation short and introduce an authoritative component in the otherwise horizontal rapport between the Court and the national judiciary. AOs are a warning signal to national courts to halt preliminary references, and thus inevitably a 'shift' for the worse when it comes to dialogue. Sometimes, they dodge the discussion of pressing societal problems in Europe (as in happened in Aziz and subsequent decisions, see Micklitz (2013). Alas, the responsibility to uphold the rule of law and uniform application across the Union does not neatly stop at the border of national political or social-economic conflict.

The findings moreover imply that the Court assesses the legal significance of repeated references from one national legal order unilaterally, according to its own conception of pan-European problems of interpretation and validity. The modus operandi is contrary to the image of preliminary rulings procedure as a conversation between courts (Witte, 2016; Rosas, 2007; Jacobs, 2003). AOs thus emerge as orders, which transform the preliminary reference procedure from a collaborative instrument of interpretation into an instrument of final dispute resolution. AOs forsake the responsibility of national courts to contribute to the development of European Union law, stripping them of their European hats. They centralize the power to decide on European legal importance in Luxembourg.

Research demonstrates that AOs have a negative effect on deliberation, and cause frustration among referring judges (Karin Leijon and Monika Glavina, 2020; Mayoral, 2016). The Court risks weakening the 'per se compliance pull of a dialogue conducted between courts in legalese' (Weiler, 1999). AOs increase efficiency in the short run at the price of long term cooperation, even when well meaning or used as a last resort. The risks of de-legitimization loom particularly large.

\section{Conclusion and Avenues for Future Research}

The Court issues collegiate judgments; it allows no separate opinions; its reasoning is abstract; its judges largely anonymous; its archives incomplete and barely accessible. So far, the (proverbially) opaque judgments have been the only inroad into the Court's law making process. This article opened a new promising avenue (the orders of the Court) and explored it from a novel perspective (through the Court's organization of its procedures). It showed that

of 1993 on unfair terms in consumer contracts. 
orders are a viable source to understand judicial behavior and the politics of judicial cooperation.

AOs actively shape the Court's relationship with national courts and tribunals. The temporal analysis demonstrates that significant developments in the AOs did not follow from the major amendments. Rather, AOs rose to prominence through a piecemeal introduction of comparably anonymous and minor adjustments of the RoP. The Court accomplished these reforms before the Treaty of Nice granted it the competence to do so. The expansion of AOs is thus the flip side of judicial self-empowerment. As the finding showed, these reforms boosted the efficiency of the Court. They also allowed the Court to use the power gained through the increased procedural flexibility to unilaterally impose its version of the conversation with national courts and tribunals. Specifically, the expanded reach and reduced procedural requirements of AOs permitted the Court to substantively transform the relationship of cooperation.

The findings indicate that the Court uses AOs as a dynamic procedural alternative to docket control. The Court issues more AOs in areas going through bouts of activity, but the probability that the Court will reply by an AO increases significantly when the preliminary questions refer to legal provisions that have been the subject of a high number of references from a single Member State. This more frequent use of AOs signals the willingness of the Court to dodge certain debates that arise due to local and legally narrow problems.

The findings moreover highlight the fact that the Court approaches certain disputes vertically. In other words, when judges of a given Member State start making more references on the same legal issue, the Court progressively takes a more authoritative approach. AOs are not only a legally compelling alternative, but mainly a strategic choice re when and how to terminate deliberation.

The findings open several promising avenues for future research.

On the basis of the RoP, it is possible to distinguish different scenarios that lead to the decision of the Court to issue an AO. While it is relatively straightforward to discern if a question is identical to a previous one or easily deducible from earlier case law, literature suggests that the case law on when a question 'admits no reasonable doubt' is more opaque regarding the factors that prompt the Court to establish that a case raises no doubts (M. Broberg, 2008). Moreover, literature has suggested a link between the criteria for issuing AOs and the doctrine of acte clair (M. Broberg, 2008; Tridimas, 2003). ${ }^{32}$ This link has been both insufficiently tested and openly denied by some members of the Court. ${ }^{33}$ Future research should investigate whether the Court uses the AO in Article 99 to signal questions that it considers to comply with the criteria of acte clair or, more broadly, whether there is any link at all between the use

\footnotetext{
${ }^{32}$ Edward (2003/ed) writing in his personal capacity argues for a middle way, in which national supreme courts in doubt as to whether the CILFIT criteria apply could refer a question mentioning specifically the possibility to obtain a reply by reasoned order. The Court has never endorsed this view.

${ }^{33}$ The Court has not specifically addressed this issue in its judgments. However, AG Tizziano in his Opinion in case C-99/00, Lyckesdog, specifically rejected this idea, arguing that 'the prerequisites and purposes' of both provisions 'are, and must be, completely different'.
} 
of Article 99 RoP and the interpretation of the Court of the CILFIT criteria. Such research would not only enrich the understanding of AOs, but it would also contribute to a better insight on what makes a case 'clear' from the point of view of European Union Law.

The findings also suggest that more research is warranted with regard to the Court's practice regarding the participation of the parties in the procedure leading to an AO: According to its internal documents, the Court has discretion to choose to inform the parties of the decision to reply by an AO. In this regard, it would be worthwhile to analyze if Member States and other parties generally submit observations in these cases, and how the Court deals with such submissions in the procedure to issue an AO. Research in this regard is important as it is conceivable that not considering the submissions of the parties might affect the quality and applicability of the ruling of the Court. ${ }^{34}$ After all, in several cases the Court has gathered relevant information for the outcome of the procedure from the submissions of the parties (see: M. P. Broberg and Fenger, 2014; Lenaerts, 1994; decision of the Court in Case C-259/91, Allué).

While this article has pointed towards strategic elements in the Court's use of AOs, it raised questions regarding the ins and outs of the dynamic between the Court and national courts in the issuing of these orders. Most importantly, the findings of this article point towards the use of AOs as tools of deterrence. Future research should further explore the role of AOs in judicial dialogue and its effects on the actions of national courts. That's (not) an order!

\section{References}

Alter, Karen J. (2009). The European Court's Political Power: Selected Essays. Oxford ; New York: Oxford University Press. 332 pp. ISBN: 978-0-19-9558353.

Barents, R. (2016). Remedies and Procedures before the EU Courts. Kluwer Law International. ISBN: 978-90-411-6614-2.

Bobek, Michal (2013). 'Of Feasibility and Silent Elephants : The Legitimacy of the Court of Justice through the Eyes of National Courts'. In: Judging Europe's Judges : The Legitimacy of the Case Law of the European Court of Justice. Ed. by Maurice Adams, Henri Clemens Ferdinand Jozef Alexander de Waele, Johan Meeusen and Gert Straetmans. Hart Publishing. ISBN: 9781-84946-335-5.

Brekke, Stein Arne, Joshua Fjestul, Daniel Naurin, Silje Synnøve Lyder Hermansen and Mikael Holmgren (n.d.). 'The CJEU Database Platform: Decisions and Decisions Makers. Codebook'. In: forthcoming ().

\footnotetext{
${ }^{34}$ In the absence of submissions of the parties, the 'fiche de préexamen' drafted by the Documentation Service at the Court gains more importance. The fiche contains a preliminary analysis of the case, the points of law it raises, its connection to other cases, the legal context in which the preliminary question arises and any other relevant element of the context of the reference. Importantly, it signals whether the case can be disposed of by means of a reasoned order. See Guide Pratique at 16.
} 
Broberg, Morten (2008). 'Acte Clair Revisited. Adapting the Acte Clair Criteria to the Demands of the Times'. In: Common Market Law Review 45.5, pp. 1383-1397. ISSN: 0165-0750. URL: http://www.kluwerlawonline.com . ezproxy. eui.eu/abstract.php?area=Journals\&id=COLA2008095 (visited on $21 / 01 / 2020)$.

Broberg, Morten P. and Niels Fenger (2014). Preliminary References to the European Court of Justice. Second edition. Oxford University Press. ISBN: 978-0-19-870402-7.

CJEU (2018). The Year in Review. Annual Report 2018. URL: https://curia. europa . eu / jcms / upload / docs / application / pdf / 2019-04/ra_pan_ 2018_en.pdf (visited on 14/10/2020).

- (2019). The Year in Review. Annual Report 2019. URL: https://curia . europa . eu / jcms / upload / docs / application / pdf / 2020 - 05/ra_pan _ 2019_interieur_en_final.pdf (visited on 14/10/2020).

Dunoff, Jeffrey L. and Mark A. Pollack (2018-2019). 'International Judicial Practices: Opening the Black Box of International Courts'. In: Michigan Journal of International Law 40.1, pp. 47-114. URL: https://heinonline. org/HOL/P?h=hein. journals/mjil40\&i=51 (visited on 13/10/2020).

Edward, David (2003/ed). 'National Courts - the Powerhouse of Community Law'. In: Cambridge Yearbook of European Legal Studies 5, pp. 1-13. Issn: 1528-8870, 2049-7636. DOI: $10.5235 / 152888712802784126$. URL: https : / / www . cambridge . org / core / journals / cambridge - yearbook - of european-legal-studies/article/national-courtsthe-powerhouseof-community-law/42D022D43F10DDA05FEF5C3C690FF040 (visited on 17/08/2020).

ERLP (2014). 'The Over-Indebtedness of European Consumers : A View from Six Countries'. In: EUI Working Paper 10. URL: http://cadmus.eui.eu/ handle/1814/32451 (visited on 13/02/2018).

Jacobs, Francis G. (2003). 'Judicial Dialogue and the Cross-Fertilization of Legal Systems: The European Court of Justice'. In: Tex. Int'l LJ 38, p. 547.

Karin Leijon and Monika Glavina (2020). 'Passive for the Same Reasons? Exploring Why National Judges Do Not Request Preliminary Rulings from the CJEU'.

Kelemen, R. Daniel (2016). 'The Court of Justice of the European Union in the Twenty-First Century'. In: Law and Contemporary Problems 79.1, pp. 117140. ISSN: 0023-9186. URL: https : //scholarship. law. duke. edu/lcp/ vol79/iss $1 / 5$.

Lasok, K. P. E. (2017). Lasok's European Court Practice and Procedure. Third edition. Bloomsbury Professional. ISBN: 978-1-84592-066-1.

Lecourt, Robert (1976). 'L'Europe Des Juges'. In:

Lenaerts, Koen (1994). 'Form and Substance in the Preliminary Reference Procedure'. In: Institutional Dynamics of European Integration. Ed. by Deirdre Curtin and Ton Heukels. M. Nijhoff. IsBN: 978-0-7923-3160-5.

Lenaerts, Koen, Ignace Maselis, Kathleen Gutman and Janek Tomasz Nowak (2014). EU Procedural Law. First edition. Oxford EU Law Library. Oxford, United Kingdom: Oxford University Press. 890 pp. ISBN: 978-0-19-870733-2. 
Martinsen, Dorte Sindbjerg (2015). An Ever More Powerful Court? The Political Constraints of Legal Integration in the European Union. First edition. Oxford University Press. ISBN: 978-0-19-181502-7.

Mayoral, Juan A. (2016). 'In the CJEU Judges Trust: A New Approach in the Judicial Construction of Europe'. In: Journal of Common Market Studies 55.3, pp. 551-568. ISSN: 1468-5965. DOI: $10.1111 / \mathrm{jcms} .12488$.

Micklitz, Hans-W. (2013). 'Mohamad Aziz - Sympathetic and Activist, But Did the Court Get It Wrong?' In: When the Court Gets It Wrong. Florence, European Constitutional Law Network. URL: http://www.ecln.net/tl_ files / ECLN / Florence \% 202013 / Micklitz \% 20 - \% 20The \% 20ECJ \% 20gets \% 20 it $\% 20$ wrong\%20Aziz-30-11-14.pdf (visited on 13/10/2020).

O'Leary, Síofra (2002). Employment Law at the European Court of Justice: Judicial Structures, Policies and Processes. Hart. ISBN: 978-1-84113-233-4.

Pescatore, Pierre (2010). 'Van Gend En Loos, 3 February 1963-A View from Within'. In: The Past and Future of EU Law : The Classics of EU Law Revisited on the 50th Anniversary of the Rome Treaty. Ed. by Miguel Poiares Maduro and Loïc Azoulai. Hart. ISBN: 978-1-84113-712-4.

Rosas, Allan (2007). 'The European Court of Justice in Context: Forms and Patterns of Judicial Dialogue'. In: Eur. J. Legal Stud. 1, p. 121.

Sánchez, Sara Iglesias (2014). 'Unfair Terms in Mortgage Loans and Protection of Housing in Times of Economic Crisis: Aziz v. Catalunyacaixa'. In: Common Market Law Review 51.3, pp. 955-974.

Skouris, Vassilios (2006). 'Self-Conception, Challenges and Perspectives of the EU Courts'. In: The Future of the European Judicial System in a Comparative Perspective. Ed. by Ingolf Pernice, Juliane Kokott and Cheryl Saunders. Baden-Baden Nomos. ISBN: 978-3-8329-2157-6.

Stone Sweet, Alec (2004). The Judicial Construction of Europe. Oxford University Press. ISBN: 978-0-19-927552-6.

Tridimas, Takis (2003). 'Knocking on Heaven's Door: Fragmentation, Efficiency and Defiance in the Preliminary Reference Procedure'. In: Common Market L. Rev. 40, p. 9.

Weiler, Joseph H. H. (1999). The Constitution of Europe: 'Do the New Clothes Have an Emperor?' and Other Essays on European Integration. Cambridge University Press. ISBN: 978-0-521-58473-9.

- (2001). 'Epilogue: The Judiciary Après Nice'. In: The European Court of Justice. Ed. by Gráinne De Búrca and Joseph H. H. Weiler. Academy of European Law, European University Institute ; Oxford University Press, ISBN: 978-0-19-924601-4.

Witte, Bruno de (2016). 'The Preliminary Ruling Dialogue : Three Types of Questions Posed by National Courts'. In: National Courts and EU Law : New Issues, Theories and Methods. Ed. by Bruno de Witte, Juan A. Mayoral, Urszula Jaremba, Marlene Wind and Karolina Podstawa. Edward Elgar Publishing. ISBN: 978-1-78347-989-4. 
Author(s): Urška Šadl, Daniel Naurin, Lucia López Zurita, Stein Arne Brekke Title: That's an Order! The Orders of the CJEU and the Effect of Article 99 RoP on Judicial Cooperation iCourts Working Paper Series, No. 219, 2020

Publication date: 20/0ctober/2020

URL: http://jura.ku.dk/icourts/working-papers/

(C) Author

iCourts Working Paper Series

ISSN: 2246-4891

Urška Šadl, Professor of Law at European University Institute, Florence, Italy, and Global Research Fellow at iCourts, University of Copenhagen, Copenhagen, Denmark. Email: urska.sadl@jur.ku.dk

Daniel Naurin, Professor of political science at the University of Oslo and Gothenburg and Director of ARENA

Email: daniel.naurin@pol.gu.se

Lucia López Zurita, PhD candidate at the European University Institute (EUI) in Florence

Email: lucia.lopez@eui.eu

Stein Arne Brekke, PhD researcher in law at the European University Institute in Florence, Italy

Email: Stein.Brekke@eui.eu

The iCourts Online Working Paper Series publishes pre-print manuscripts on international courts, their role in a globalising legal order, and their impact on politics and society and takes an explicit interdisciplinary perspective.

Papers are available at http://jura.ku.dk/icourts/

\section{iCourts}

- The Danish National Research Foundation's Centre of Excellence for International Courts The Faculty of Law University of Copenhagen

Karen Blixens Plads 16 2300 Copenhagen S

E-mail: icourts@jur.ku.dk

Tel. +4535322626 